\title{
Airborne in-situ measurements of vertical, seasonal and latitudinal distributions of carbon dioxide over Europe
}

\author{
Ch. Gurk ${ }^{1}$, H. Fischer ${ }^{1}$, P. Hoor ${ }^{1}$, M. G. Lawrence ${ }^{1}$, J. Lelieveld ${ }^{1}$, and H. Wernli ${ }^{2}$ \\ ${ }^{1}$ Max Planck Institute for Chemistry, POB 3060, 55020 Mainz, Germany \\ ${ }^{2}$ Institute for Atmospheric Physics, University of Mainz, Germany \\ Received: 12 February 2008 - Published in Atmos. Chem. Phys. Discuss.: 16 April 2008 \\ Revised: 25 September 2008 - Accepted: 29 September 2008 - Published: 10 November 2008
}

\begin{abstract}
Airborne in-situ observations of carbon dioxide $\left(\mathrm{CO}_{2}\right)$ were made during 7 intensive measurement campaigns between November 2001 and April 2003 as part of the SPURT project. Vertical profiles and latitudinal gradients in the upper troposphere/lowermost stratosphere were measured along the western shore of Europe from the subtropics to high northern latitudes during different seasons. In the boundary layer, $\mathrm{CO}_{2}$ exhibits a strong seasonal cycle with the maximum mixing ratios in winter and minimum values in summer, reflecting the strength of $\mathrm{CO}_{2}$ exchange with vegetation. Seasonal variations are strongest in high latitudes and propagate to the free troposphere and lowermost stratosphere, although with reduced amplitude. In the lowermost stratosphere, the $\mathrm{CO}_{2}$ seasonal cycle is phase-shifted relative to the free troposphere by approximately 3 months, with highest mixing ratios during the summer. Modelling studies support the interpretation that altitude gradients of $\mathrm{CO}_{2}$ are likely due to stratosphere-troposphere-transport.
\end{abstract}

\section{Introduction}

Next to water vapour $\left(\mathrm{H}_{2} \mathrm{O}\right)$, carbon dioxide $\left(\mathrm{CO}_{2}\right)$ is the most important greenhouse gas in the atmosphere, and its mixing ratio has increased from approximately $280 \mathrm{ppm}$ in the pre-industrial 19th century to approximately $380 \mathrm{ppm}$ today (WMO, 2006). Long-term observations since 1958 (Keeling, 1998) indicate that the atmospheric concentration of $\mathrm{CO}_{2}$ has been increasing at a rate of approx. $1.9 \mathrm{ppm} / \mathrm{year}$ (Forster et al., 2007) due to anthropogenic activities, in particular the combustion of fossil fuels and deforestation. This ongoing trend causes significant changes in the radia-

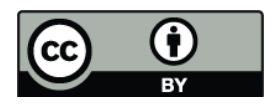

Correspondence to: H. Fischer (hofi@ mpch-mainz.mpg.de) tion budget of the atmosphere, affecting our climate (Taylor, 2005; Intergovernmental Panel on Climate Change, 2001).

To budget the sources and sinks of atmospheric $\mathrm{CO}_{2}$ high precision measurements are needed. These are provided for a large number of background ground-based stations by the World Meteorological Organisation (WMO) Global Atmospheric Watch (GAW) Global Greenhouse Gas Monitoring Network (http://gaw.kishou.go.jp) and the National Oceanic and Atmospheric Administration (NOAA) Earth System Research Laboratory (ESRL) Global Monitoring Division (http://www.cmdl.noaa.gov), but information about the vertical distribution of $\mathrm{CO}_{2}$ in the atmosphere is rather limited. Stephens et al. (2007) in a recent publication emphasized that this vertical information is necessary to improve $\mathrm{CO}_{2}$ budget calculations based on inverse modelling. Despite recent progress in satellite-based $\mathrm{CO}_{2}$-column observations (e.g. Chedin et al., 2003; Buchwitz et al., 2005; Engelen and McNally, 2005; Barclay et al., 2006; Tiwari et al., 2006), measurements of $\mathrm{CO}_{2}$ in the free troposphere and the lower stratosphere are restricted to a small number of balloon- and airborne measurement campaigns (e.g. Pearman and Beardsmore, 1984; Nakazawa et al., 1991; Matsueda and Inoue, 1996; Anderson et al., 1996; Boering et al., 1996; Vay et al., 1999; Zahn et al., 1999; Matsueda et al., 2002; Machida et al., 2003; Aoki et al., 2003; Sawa et al., 2004; Lin et al., 2006).

In particular, systematic investigations of the seasonal and latitudinal variation of $\mathrm{CO}_{2}$ above the boundary layer are sparse and limited to the western Pacific region (Nakazawa et al., 1991; Matsueda and Inoue, 1996; Matsueda et al., 2002; Machida et al., 2003). Here we report measurements of free tropospheric and lowermost stratospheric $\mathrm{CO}_{2}$ mixing ratios during all seasons covering the latitude range from $35^{\circ} \mathrm{N}$ to $75^{\circ} \mathrm{N}$ in the European longitudinal sector between $10^{\circ} \mathrm{W}$ and $20^{\circ} \mathrm{E}$ obtained during the SPURT (SPURenstofftransport in der Tropopausenregion, German for "trace gas transport in the tropopause region") project (Engel et al., 2006).

Published by Copernicus Publications on behalf of the European Geosciences Union. 


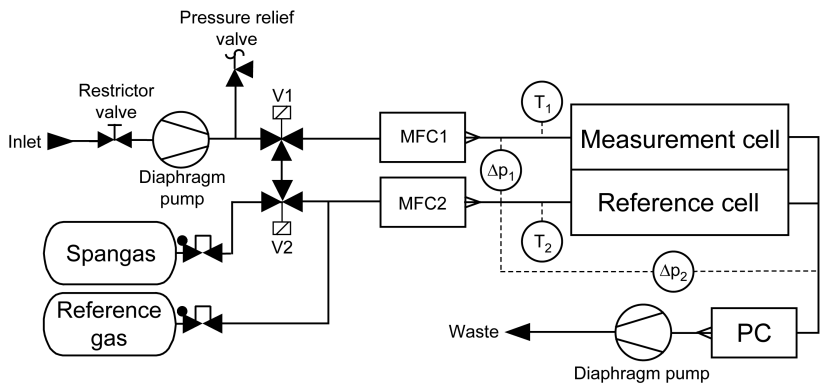

Fig. 1. Diagram of the gas flow for the FABLE instrument (MFC $=$ mass flow controller; $\mathrm{PC}=$ personal computer). See text for details.

We analyse the data and study seasonal and latitudinal variations of $\mathrm{CO}_{2}$ vertical profiles from the boundary layer to the lowermost stratosphere up to potential temperatures of $370 \mathrm{~K}$ at about $14 \mathrm{~km}$ altitude.

\section{The FABLE instrument}

Airborne $\mathrm{CO}_{2}$ measurements were made with the Fast Aircraft-Borne Licor Experiment (FABLE), that consists of a commercial $\mathrm{CO}_{2} / \mathrm{H}_{2} \mathrm{O}$ analyser (LI-6262, LI-COR Inc.) modified for airborne operation. The principle of $\mathrm{CO}_{2}$ measurements with the LI-6262 relies on differential nondispersive infra-red (IR) absorption spectroscopy between geometrically identical sampling and reference cells. A vacuum-sealed IR-light beam is directed through both cells, whose emission frequency corresponds to a black body at $1250 \mathrm{~K}$. The optical path outside the cells is purged with $\mathrm{H}_{2} \mathrm{O}$ and $\mathrm{CO}_{2}$ scrubbed air $\left(\mathrm{Mg}\left(\mathrm{ClO}_{4}\right)_{2}\right.$-filter). The differential absorption between signal- and reference cell is measured with two PbSe-detectors. Water vapour is measured with a filter centred at $2.59 \mu \mathrm{m}$ (filter width $50 \mathrm{~nm}$ ) while $\mathrm{CO}_{2}$ is detected at $4.26 \mu \mathrm{m}$ (width $150 \mathrm{~nm}$ ).

A mechanical chopper alternatively blocks the transmission through either the reference or the signal cell, so that the detectors receive a difference signal between both cells. The signal is strongly dependent on the pressure in both cells and the temperature of the gas. Since water affects the $\mathrm{CO}_{2}$ measurements by spectroscopic interference in the $\mathrm{CO}_{2}$ band, pressure broadening and dilution an accurate determination of the water vapour concentration is necessary to correct the $\mathrm{CO}_{2}$ readings of the instrument in particular for tropospheric applications (Daube et al., 2002). Therefore the $\mathrm{H}_{2} \mathrm{O}$ measurements of the LI-6262 have been compared to a dew point hygrometer (Model 2003 Dewprime III, EdgeTech, Milford, MA, USA), indicating a total uncertainty of the FABLE water vapour measurements of $5 \%$ for concentrations above $100 \mathrm{ppm}$.

To operate the system on board of a research aircraft and perform high precision measurements, several modifications of the LI-6262 were necessary. In particular, a high preci- sion flow system is required, since both the ambient pressure outside the aircraft and the cabin pressure depend on flight altitude. Figure 1 shows the flow system built for FABLE. Ambient pressure varies between about $1030 \mathrm{hPa}$ in the boundary layer and less than $200 \mathrm{hPa}$ at the highest flight levels.

Sampling is accomplished via a $1 / 2^{\prime \prime}$ stainless steel sampling tube pointing into the flight direction. The sample gas is pressurized to about $1150 \mathrm{hPa}$ by a three-stage Teflon diaphragm-pump (model MD 1 VARIO, Vacuubrand, Germany). A restrictor valve on the low-pressure side of the pump controls the flow in the boundary layer. On the highpressure side, a pressure relief valve establishes a constant pressure approximately $150 \mathrm{hPa}$ higher than cabin pressure. Via a low $\Delta p$ mass flow controller (MFC 1: Bronkhorst, The Netherlands) the pressure ahead of the measurement cell is regulated to $850 \mathrm{hPa}$, while the pressure ahead of the MFC varies between 1150 and $950 \mathrm{hPa}$ as a function of the cabin pressure. The time resolution determined as the time constant for a signal change from 5 to $95 \%$ is of the order of $4 \mathrm{~s}$ for the system including the constant pressure inlet.

The reference cell is purged by a $100 \mathrm{sccm}$ flow of reference gas from a gas tank, at a pressure of $850 \mathrm{hPa}$ regulated via MFC 2, to allow a differential measurement between the two cells held at the same pressure. Since the cell absorption and thus the analyser output are non-linear functions of the $\mathrm{CO}_{2}$ mixing ratio a multi-point polynominal calibration function has been obtained in the laboratory by using 4 different NOAA reference gas standards.

In flight, the reference gas is used as a secondary calibration gas which can be added to the measurement cell via valves V1 and V2. Additionally, a second standard (Spangas) is used for in-flight calibrations of the instrument span. Both standards are compared in the laboratory to two primary NOAA reference standards with concentrations of 366.34 and $390.11 \mathrm{ppm}$, respectively.

To avoid temperature drifts of the instrument, the whole analyser is mounted in a sealed box that is actively temperature controlled.

The in-flight noise level determined from ambient measurements during periods of low atmospheric variability is about $0.06 \mathrm{ppm}(1 \sigma)$. This noise is a measure for the shortterm precision of the instrument. The long-term precision of FABLE is additionally affected by changes in the instrument sensitivity over the flight. It is determined as the reproducibility of the in-flight calibrations that varies from flight to flight between 0.050 and $0.300 \mathrm{ppm}(1 \sigma)$. The calibration accuracy $(0.109 \mathrm{ppm}, 1 \sigma)$ is determined by the in-flight standards. Thus the total uncertainty of the $\mathrm{CO}_{2}$ measurement with FABLE is estimated at $0.366 \mathrm{ppm}(1 \sigma)$, roughly $0.1 \%$ of the ambient mixing ratio. This corresponds to an improvement by roughly a factor 2 compared to the analyser specifications provided by LI-Cor inc., which is mainly achieved by the temperature and pressure stabilization of the FABLE instrument. 


\section{Measurements during SPURT}

A total of eight 2-day measurement campaigns covering all seasons were performed within SPURT during the time periods 10-11 November 2001; 17-19 January, 16-17 May, 2223 August and 17-18 October 2002; 15-16 February, 27-28 April and 9-10 July 2003. Carbon dioxide measurements were obtained during the first 7 campaigns; for the last one data are missing due to an instrument failure. All campaigns were flown out of the aircraft's home base Hohn in northern Germany $\left(54^{\circ} \mathrm{N}, 9^{\circ} \mathrm{E}\right)$. A typical campaign consisted of at least two southbound flights within one day, followed by two or more northbound flights performed on the next day. Thus a series of flights covered the latitude range between approximately $35^{\circ}$ and $75^{\circ} \mathrm{N}$ along the western shore of Europe. During stop-over landings at airports in the subtropics (Faro (Portugal, $37^{\circ} \mathrm{N}, 8^{\circ} \mathrm{W}$ ), Casablanca (Morocco, $\left.33^{\circ} \mathrm{N}, 7^{\circ} \mathrm{W}\right)$, Gran Canaria $\left(28^{\circ} \mathrm{N}, 15^{\circ} \mathrm{W}\right)$, Lisbon (Portugal, $38^{\circ} \mathrm{N}, 9^{\circ} \mathrm{W}$ ), Jerez (Spain, $36^{\circ} \mathrm{N}, 6^{\circ} \mathrm{W}$ ), Monastir (Tunisia, $35^{\circ} \mathrm{N}, 10^{\circ} \mathrm{E}$ ), Sevilla (Spain, $37^{\circ} \mathrm{N}, 5^{\circ} \mathrm{W}$ )) and at high northern latitudes (Kiruna (Sweden, $68^{\circ} \mathrm{N}, 20^{\circ} \mathrm{E}$ ), Tromsö (Norway, $69^{\circ} \mathrm{N}, 18^{\circ} \mathrm{E}$ ), Keflavik (Iceland, $64^{\circ} \mathrm{N}$, $22^{\circ} \mathrm{W}$ ), Longyearbyen (Norway, $78^{\circ} \mathrm{N}, 15^{\circ} \mathrm{E}$ )) two profiles between ground-level and approximately $14 \mathrm{~km}$ altitude were obtained during landing and take-off (see Fig. 1 of Fischer et al., 2006). Detailed descriptions of the individual campaigns can be found in the overview article by Engel et al. (2006).

\section{Results}

\subsection{Comparison with GAW observations}

To compare the airborne measurements during SPURT with ground-based observations, Fig. 2 shows data from the GAW station Zugspitze $\left(47.25^{\circ} \mathrm{N}, 10.59^{\circ} \mathrm{E}, 2960 \mathrm{~m}\right.$ a.s.l.) (data obtained from: (http://gaw.kishou.go.jp) as measured by the German Umweltbundesamt. This site has been chosen because it is considered to be representative for mid-latitudes where we obtained profiles from the SPURT measurements. To avoid direct contamination at the surface in close proximity to the airports, the comparison is made for a mountain site. Also shown in the figure are SPURT observations from landings and take offs in Hohn, averaged within $1 \mathrm{~km}$ thick altitude bins corresponding to the height of the station. The airborne observations closely follow the daily variations at the station and deviations generally do not exceed $1 \mathrm{ppm}$ (mean difference $=-0.2 \mathrm{ppmv}$ ), which underlies both the accuracy and representativity of the SPURT data.

\subsection{Vertical profiles}

Average profiles of $\mathrm{CO}_{2}$ mixing ratios for the individual campaigns are shown in Fig. 3. Mean values and $1 \sigma$-standard deviations for $1 \mathrm{~km}$ altitude bins have been calculated from take-offs and initial ascent as well as during the final descents

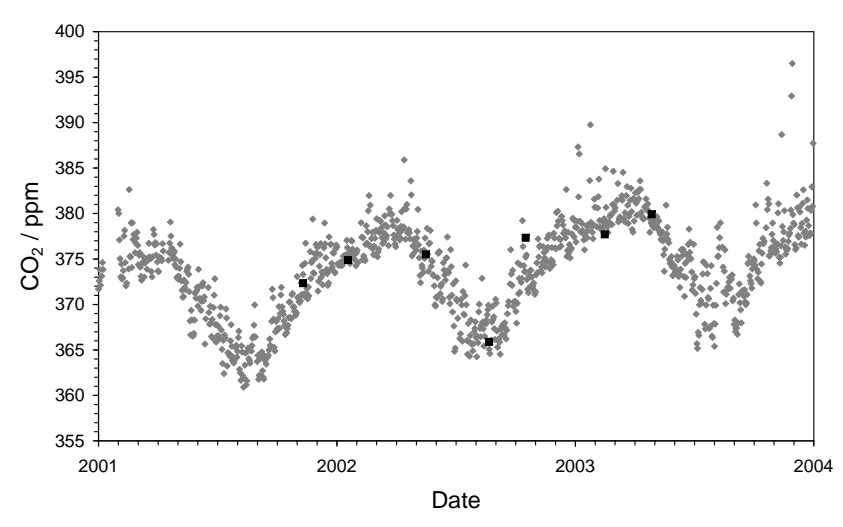

Fig. 2. Comparison of mean airborne observations from SPURT (black symbols) with daily measurements (grey symbols) at the GAW stations Zugspitze.

at high $\left(>65^{\circ} \mathrm{N}\right.$, blue lines), middle (approx. $55^{\circ} \mathrm{N}$, green lines) and subtropical latitudes $\left(<40^{\circ} \mathrm{N}\right.$, red lines).

Significant latitudinal variations are observed in the lower layers of the troposphere (below $5 \mathrm{~km}$ ), in particular during the summer/fall transition (August to October 2002). In the boundary layer below $\sim 1 \mathrm{~km}$ a latitudinal gradient of about $-0.2 \mathrm{ppm} /$ degree latitude is observed between $35^{\circ} \mathrm{N}$ and north of $55^{\circ} \mathrm{N}$ during August 2002, maximizing in October 2002 at about $-0.35 \mathrm{ppm} /$ degree latitude between $<50^{\circ} \mathrm{N}$ and $65^{\circ} \mathrm{N}$. These strong latitudinal gradients at low altitudes in summer reflect the enhanced up-take by vegetation during the growing season. This sink is strongest at high latitudes (blue lines in Fig. 3d and e) yielding a $\mathrm{CO}_{2}$ profile with lowest concentrations close to the ground. This effect is much smaller at lower latitudes. In the late winter/early spring seasons (in particular during April 2003) when boundary layer mixing ratios are highest, a latitudinal gradient is not discernable.

In general, only small seasonal differences between different latitude bands are found in the middle troposphere between 5 and $9 \mathrm{~km}$. Above $9 \mathrm{~km}$ in the upper troposphere/lowermost stratosphere again significant latitudinal gradients are observed in particular during the spring season (May 2002 and April 2003). In the tropopause region these latitudinal differences are mainly related to differences in the tropopause height (determined as the 2 PVU surface with $1 \mathrm{PVU}=10^{-6} \mathrm{~m}^{2} \mathrm{~s}^{-1} \mathrm{Kkg}^{-1}$ ), with a generally low tropopause at high latitudes and a high tropopause at low latitudes, in particular during the spring season (Fig. $3 \mathrm{c}$ and g).

The individual profiles shown in Fig. 3 can be influenced by synoptic transport and mixing, leading to local variations in atmospheric $\mathrm{CO}_{2}$ that do not necessarily reflect climatological meridional gradients. Thus advection from different latitudes and altitudes may be responsible for at least part of the observed variability in individual profiles (Gerbig et al., 2003). 


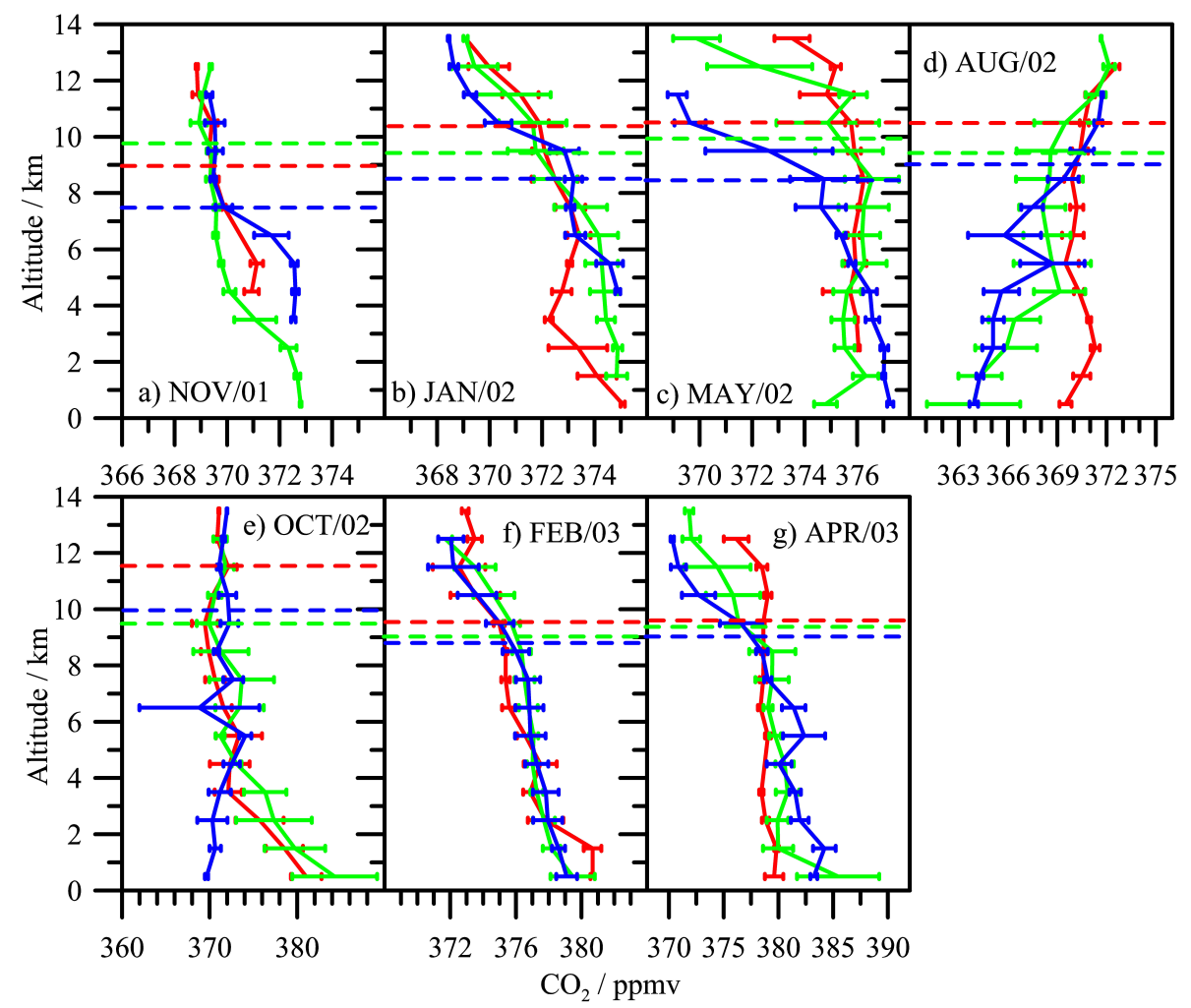

Fig. 3. Means and $1 \sigma$-standard deviation for $1 \mathrm{~km}$ altitude bins calculated from take-offs and landings at high $\left(>65^{\circ} \mathrm{N}\right.$, blue lines), middle (approx. $55^{\circ} \mathrm{N}$, green lines) and subtropical latitudes $\left(<40^{\circ} \mathrm{N}\right.$, red lines). Horizontal dashed lines indicate the tropopause altitude.
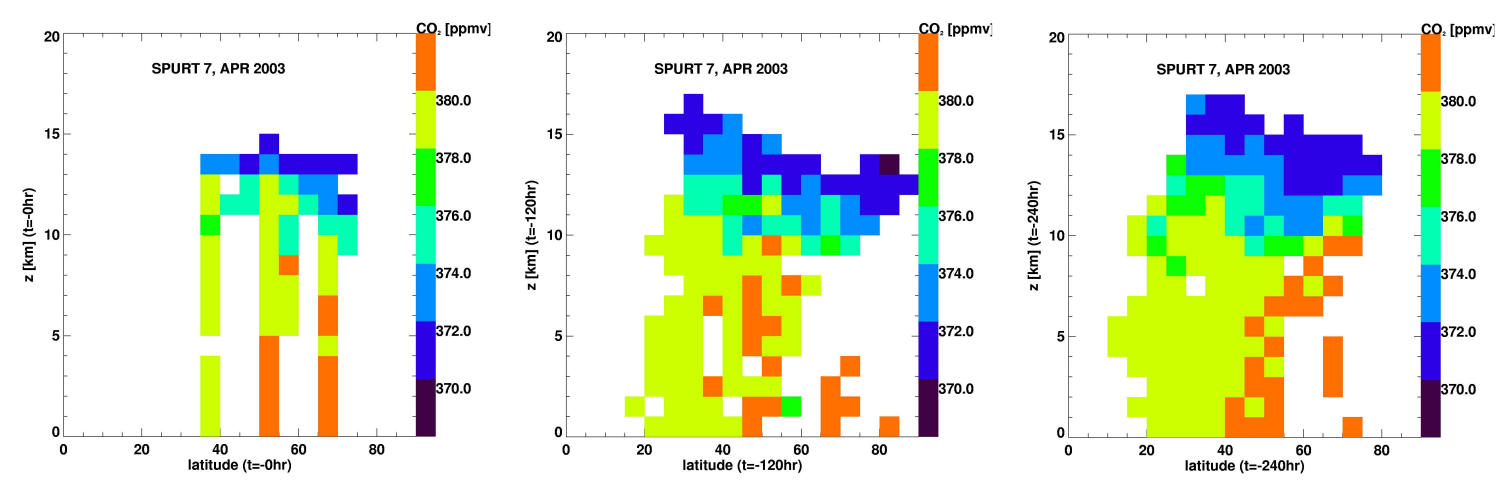

Fig. 4. Meridional cross-sections of $\mathrm{CO}_{2}$ observations from SPURT mission 7 in April 2003 in $5^{\circ}$ latitude and $1 \mathrm{~km}$ altitude bins. The left panel shows the in-situ observations while the middle and right panels show the calculated $\mathrm{CO}_{2}$ distributions 5 and 10 days back in time, respectively, based on 10-day backward trajectories.

To study the effect of transport on the individual profiles we used the Lagranto trajectory model (Wernli and Davies, 1997) to calculate 10-day backward trajectories based on 3hourly operational ECMWF analysis fields of horizontal and vertical winds. The trajectories were started every $10 \mathrm{~s}$ along the flight tracks of each SPURT mission. As an example, Fig. 4 shows all $\mathrm{CO}_{2}$ measurements obtained during SPURT mission 7 in April 2003, averaged in altitude $(1 \mathrm{~km})$ and latitude $\left(5^{\circ}\right)$ bins. The left panel shows the in-situ observations with the average profiles obtained during take-off and landing at Lisbon $\left(38^{\circ} \mathrm{N}\right)$, Hohn $\left(54^{\circ} \mathrm{N}\right)$ and Kiruna $\left(68^{\circ} \mathrm{N}\right)$, as well as the observations in the upper troposphere and lowermost stratosphere during the flights between these airports. As in Fig. $3 \mathrm{~g}$ one can identify a small latitudinal gradient in the lower troposphere, with lowest mixing ratios in the subtropics, as well as local enhancements in the upper troposphere at mid (around $8 \mathrm{~km}$ ) and high latitudes (between 5 and $7 \mathrm{~km})$. 


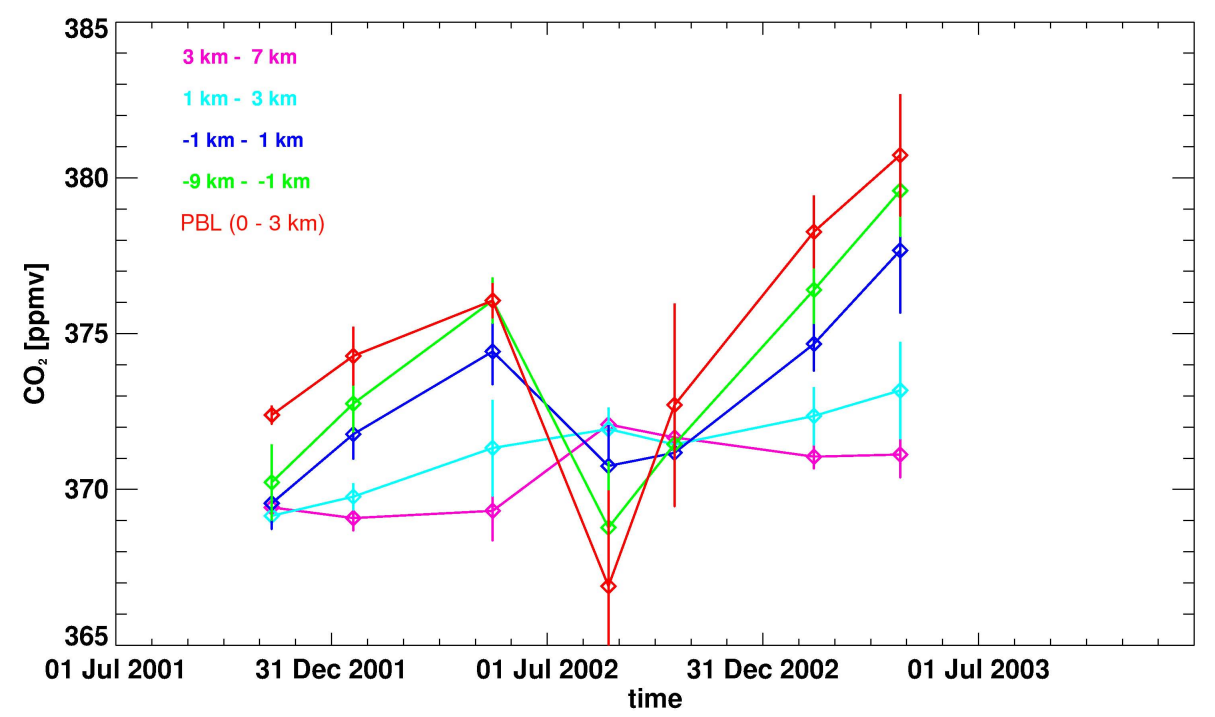

Fig. 5. Seasonal variation of $\mathrm{CO}_{2}$ mixing ratios in different atmospheric altitude sections relative to the 2-pvu tropopause and in the planetary boundary layer at the measurement locations.

The middle and right panels of Fig. 4 show the distribution of the measured $\mathrm{CO}_{2}$ values advected backwards to the corresponding altitude and latitude of the sampled air parcels 120 and $240 \mathrm{~h}$ back in time, respectively. In particular for the $240 \mathrm{~h}$ time period a large-scale ordering of the data appears, with a high-altitude low-stratosphere cluster characterized by $\mathrm{CO}_{2}$ mixing ratios below $374 \mathrm{ppm}$, and a weak though clear latitudinal gradient in the troposphere with the highest values toward the high latitudes. Note that a similar structuring has been obtained for all campaigns. In general, the strongest vertical gradients are observed around the tropopause, while the latitudinal gradients in the troposphere are rather small.

\subsection{Seasonal variations}

The seasonal variation is illustrated in Fig. 5. Considering that Fig. 3 and 4 show only small latitudinal differences above the boundary layer, all data have been grouped with respect to distance to the local tropopause, defined as the 2 PVU (potential vorticity unit) surface (Hoor et al., 2004), including constant level flight legs and independent of the latitude of observation. For this purpose the data have been averaged for the boundary layer (0-3 km, red line in Fig. 5), the free troposphere (from the boundary layer to $1 \mathrm{~km}$ below the tropopause, green line), the tropopause region defined as $1 \mathrm{~km}$ below to $1 \mathrm{~km}$ above the local tropopause (purple line), the extra-tropical tropopause layer ( 1 to $3 \mathrm{~km}$ above the local tropopause, blue line) and the lowermost stratosphere (3$7 \mathrm{~km}$ above the tropopause, pink line).

The $\mathrm{CO}_{2}$ mixing ratios at all atmospheric levels exhibit a temporal trend with increasing concentrations from November 2001 to April 2003. This increase is strongest in the lowest three kilometres $\left(\Delta \mathrm{CO}_{2}=4 \mathrm{ppm}\right.$ from January
2001 to February 2002), getting smaller (3.7 ppm) in the free troposphere and smallest in the lowermost stratosphere ( $\triangle \mathrm{CO}_{2}=2 \mathrm{ppm}$ from 1 to $7 \mathrm{~km}$ above the local tropopause).

In addition, a strong seasonal variation is observed. In the boundary layer, lowest mixing ratios are observed during $\mathrm{Au}-$ gust 2002 after a decrease of 9.3 ppm below the spring maximum, followed by a strong increase of about $11 \mathrm{ppm}$ until December 2002. A similar seasonal variation in phase with the boundary layer concentrations is observed in the free troposphere although with reduced amplitude $\left(\triangle \mathrm{CO}_{2}=-4 \mathrm{ppm}\right.$ and $+7 \mathrm{ppm}$ from May 2002 to August 2002 and August 2002 to December 2002, respectively). This is in good agreement with observations by Nakazawa et al. (1993) who observed seasonal variations of the order of $10 \mathrm{ppm}$ in the boundary layer decreasing to $7 \mathrm{ppm}$ in the altitude range between $8 \mathrm{~km}$ to the local tropopause and confirms the model simulations performed by Olsen and Randerson (2004), indicating that column $\mathrm{CO}_{2}$ has less variability than surface $\mathrm{CO}_{2}$.

Note that the SPURT measurements are only snapshots that do not provide a complete seasonal cycle. Thus the stated temporal trends - in particular the exact timing of the extremes in the seasonal variation - could well be spurious and detailed comparisons with seasonal variations of $\mathrm{CO}_{2}$ at ground-based sites are difficult.

As already mentioned by Hoor et al. (2004) the seasonal variation differs between the lowermost stratosphere and the troposphere. Contrary to a local maximum in spring and a minimum in summer found in the troposphere, $\mathrm{CO}_{2}$ mixing ratios in the lowermost stratosphere exhibit a pronounced maximum in summer and a broad minimum in winter and spring. The amplitude of the seasonal variation in the lowermost stratosphere is $\sim 3 \mathrm{ppm}$, slightly lower than found in the free troposphere and phase shifted by approx. 3 months, 

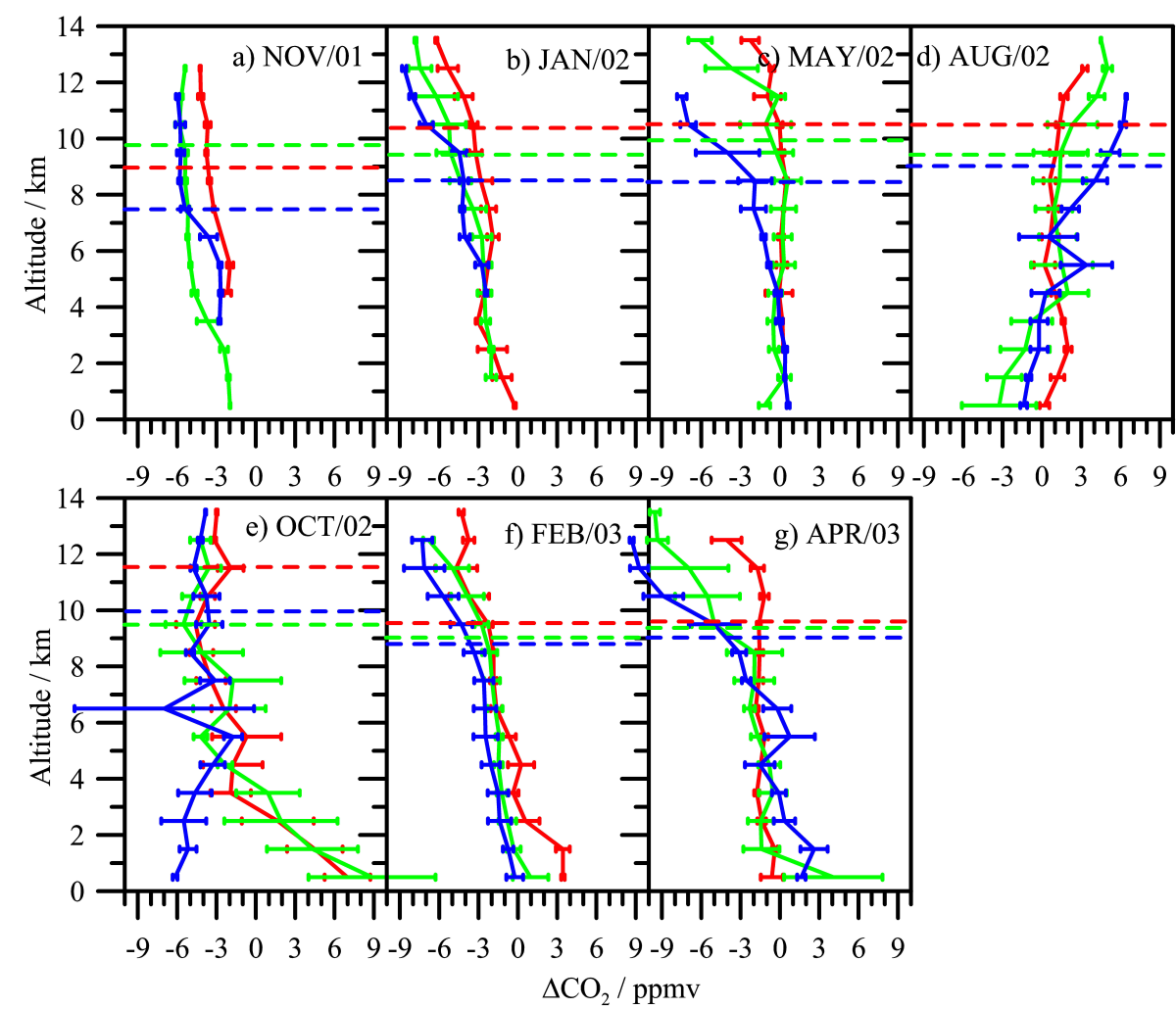

Fig. 6. Vertical profiles of the differences between measured $\mathrm{CO}_{2}$ and the marine boundary layer reference value at the same latitude (obtained from GLOBALVIEW-CO2 2006 data set) at high $\left(>65^{\circ} \mathrm{N}\right.$, blue lines), middle (approx. $55^{\circ} \mathrm{N}$, green lines) and subtropical latitudes $\left(<40^{\circ} \mathrm{N}\right.$, red lines). Horizontal dashed lines indicate the tropopause altitude.

in agreement with observations by Nakazawa et al. (1991). According to Hoor et al. (2004) this phase lag is due to longer transit times for the tropospheric fraction of air mixed into the lowermost stratosphere, and likely a different transport pathway. For a detailed discussion of the $\mathrm{CO}_{2}$ seasonal cycle in the lowermost stratosphere and its relationship to cross-tropopause transport the reader is referred to Strahan et al. (1998), Hoor et al. (2004, 2005) and Strahan et al. (2007).

\subsection{Comparison to a marine boundary layer reference}

Next we investigate the difference between the free tropospheric $\mathrm{CO}_{2}$ values and mixing ratios observed in the marine boundary layer (MBL reference) (Masarie and Tans, 1995). The MBL reference includes longitudinally averaged observations within the marine boundary layer as a function of time (weekly values) and sine of latitude (GLOBALVIEW 2006 data products are available at (http://www. esrl.noaa.gov/gmd/ccgg/globalview/). Considering the absence of direct observations and for comparison purposes we use the MBL reference also for the free troposphere (Lin et al., 2006).

In Fig. 6 the difference $\Delta \mathrm{CO}_{2}$ between $\mathrm{CO}_{2}$ (SPURT) and $\mathrm{CO}_{2}$ (MBL) is plotted as a function of altitude for the SPURT profiles obtained during the 7 campaigns. In the boundary layer (below $3 \mathrm{~km}) \Delta \mathrm{CO}_{2}$ is small during winter and spring (less than $3 \mathrm{ppm}$ ), while larger deviations are observed during summer at middle and high latitudes, a signature of strong uptake by the vegetation. SPURT measurements at high latitudes during October 2002 are still $\sim 6 \mathrm{ppm}$ lower than the MBL reference, a remainder of the summertime biosphere sink. In contrast, mixing ratios at middle and low latitudes are higher than the MBL reference by 6-9 ppm. Probably this is due to local emissions in the proximity of airports, typically located in populous regions.

Above the boundary layer we find a gradual decrease of $\Delta \mathrm{CO}_{2}$ with altitude, in particular during the fall and winter seasons. These negative values extend into the lowermost stratosphere, were lowest values up to $-9 \mathrm{ppm}$ are reached. The $\Delta \mathrm{CO}_{2}$-altitude gradient reverses in summer, with increasing values of $\Delta \mathrm{CO}_{2}$ up to $+3 \mathrm{ppm}$ above the tropopause. In spring, during the transition from negative to positive gradients, $\Delta \mathrm{CO}_{2}$ is negligible throughout the troposphere and only slightly negative in the lowermost stratosphere, in particular at low and middle latitudes. Systematic deviations between free tropospheric observations and the MBL reference have been explained in the literature by advection from different latitudes and time lags related to the vertical 
propagation of concentration changes from the surface to the free troposphere (Gerbig et al., 2003).

The near-continual decrease of $\Delta \mathrm{CO}_{2}$ with altitude in fall and winter, as well as the steady increase during summer could also be caused by the influence of stratospheretroposphere transport (STT) on the vertical profiles (Sawa et al., 2004; Shia et al., 2006). In the fall and winter seasons the enhanced downward transport (compared to the summer season) of aged $\mathrm{CO}_{2}$-poor air from the stratosphere yields lower values of $\mathrm{CO}_{2}$ in the upper troposphere relative to the MBL reference $\left(\triangle \mathrm{CO}_{2}<0\right)$. Thus the $\Delta \mathrm{CO}_{2}$-altitude relation follows a mixing line between a $\mathrm{CO}_{2}$-poor stratospheric reservoir and the MBL reference. Since the influence of STT on trace gas concentrations decreases with distance from the tropopause, $\Delta \mathrm{CO}_{2}$ declines to zero at lower altitudes.

In summer the situation reverses due to the higher $\mathrm{CO}_{2}$ concentrations in the stratosphere relative to the MBL reference $\left(\Delta \mathrm{CO}_{2}>0\right)$, yielding higher $\Delta \mathrm{CO}_{2}$ in the UT and zero in the middle and lower troposphere. In spring, when altitude gradients are weak, the signature of STT is negligible, since the mixing line connects reservoirs with similar $\mathrm{CO}_{2}$ mixing ratios in the stratosphere and troposphere.

This interpretation is in line with $\mathrm{CO}$ and $\mathrm{O}_{3}$ profiles simultaneously obtained during SPURT (not shown). Fischer et al. (2006) compared the observed $\mathrm{CO}$ and $\mathrm{O}_{3}$ profiles to 3D-chemical transport model (CTM) simulations by the MPI-C Model for Atmospheric Chemistry and Transport (MATCH-MPIC) (Lawrence et al., 2003). A tracer for stratospheric $\mathrm{O}_{3}$ calculated in the model can be used to estimate the contribution of stratospheric ozone to the $\mathrm{O}_{3}$ burden in the troposphere. In Fig. 7 this fraction (modelled stratospheric $\mathrm{O}_{3}$ /modelled total $\mathrm{O}_{3}$ ) has been plotted versus $\Delta \mathrm{CO}_{2}$ for the summer and winter seasons, respectively. Both seasons show a significant linear relationship. The strongest correlations are found at middle and high latitudes $\left(R^{2}>0.8\right)$, while weaker correlation coefficients are deduced for low latitudes ( $R^{2}$ between 0.4 and 0.6 ). This finding from the model simulations supports the interpretation that the observed altitude gradients of $\Delta \mathrm{CO}_{2}$ are likely due to STT.

\section{Summary and conclusions}

In the present work we describe airborne $\mathrm{CO}_{2}$ measurements over Western Europe covering altitudes from the planetary boundary layer up to the lowermost stratosphere and latitudes from the Artic to the sub-tropics. These measurements have been performed during all seasons as part of the SPURT project between November 2001 and April 2003. With the exception of summer all seasons have been probed twice. In addition to latitudinal gradients in the upper troposphere and lowermost stratosphere, ascents and descents into airports at high $\left(>65^{\circ} \mathrm{N}\right)$, middle $\left(\sim 55^{\circ} \mathrm{N}\right)$ and subtropical $\left(<40^{\circ} \mathrm{N}\right)$ latitudes provided data on vertical gradients over generally small, low-duty airports. This allows a comparison of the

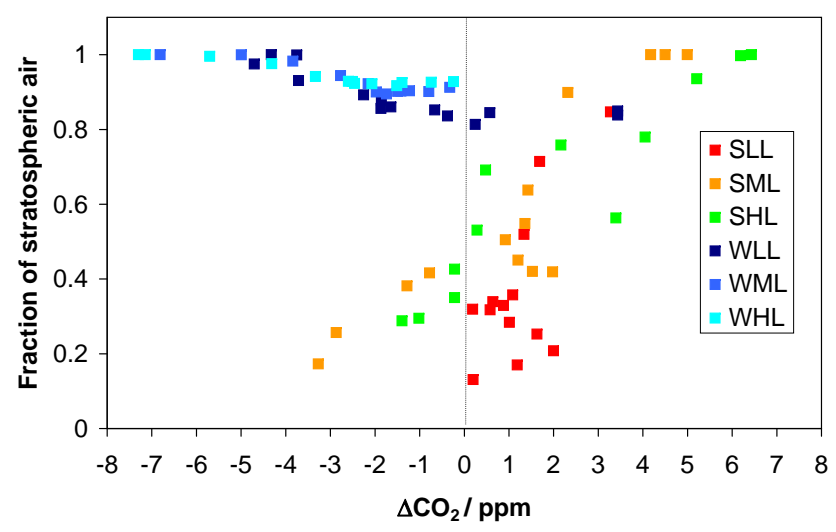

Fig. 7. Fraction of modelled stratospheric $\mathrm{O}_{3}$ to the modelled total $\mathrm{O}_{3}$ versus $\Delta \mathrm{CO}_{2}$ for the summer $(\mathrm{S})$ and winter $(\mathrm{W})$ seasons, respectively. The data are further subdivided into low latitudes (LL), mid latitudes (ML) and high latitudes (HL).

seasonal variation of $\mathrm{CO}_{2}$ in the continental boundary layer (CBL), the free troposphere and the region above the local tropopause at different latitudes.

As expected, seasonal variations and latitudinal gradients are largest in the CBL, reflecting the role of surface sources and sinks. The strongest changes are due to the up take by vegetation, which maximizes in late summer, resulting in inverted profiles with increasing concentrations with altitude. During the other seasons $\mathrm{CO}_{2}$ tends to decrease with altitude. In the free troposphere, seasonal as well as latitudinal variations typically have a strongly reduced amplitude compared to the CBL. The comparison of our measurements to a marine boundary layer reference obtained from the GLOBALVIEW data indicates that the damping of the free tropospheric seasonal cycle and latitudinal gradients are due to mixing with aged air masses, probably transported down from the lowermost stratosphere. Directly above the tropopause, i.e. in the extra-tropical tropopause layer, the seasonal cycle is in phase with the upper troposphere, but deeper into the stratosphere it is phase-shifted by approximately 3 months, indicating transport of aged air from the overworld mixed with air masses horizontally transported from the tropics, as suggested by Hoor et al. (2004, 2005).

As a final note, the data presented in this paper are freely available from the SPURT server (http://www.iac.ethz.ch/ staff/dominik/spurt/index.html) after signing the data protocol. These data could be of value in inverse modelling and satellite validation studies.

Acknowledgements. We acknowledge funding from the German Ministry for Education and Research BMBF under the AFO2000 Program. We thank the Learjet team (enviscope and GFD) for excellent cooperation during the field campaigns. HW thanks Meteo Swiss for granting access to operational ECMWF data.

Edited by: M. Heimann and U. Pöschl 


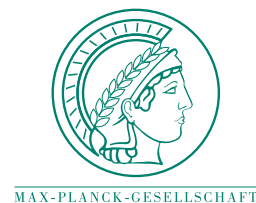

This Open Access Publication is financed by the Max Planck Society.

\section{References}

Anderson, B. E., Gregora, G. L., Collins Jr., J. E., Sachse, G. W., Conway, T. J., and Whitin, G. P.: Airborne observations of spatial and temporal variability of tropospheric carbon dioxide, J. Geophys. Res., 101, 1985-1997, 1996.

Aoki, S., Nakazawa, T., Machida, T., Sugawara, S., Morimoto, S., Hashida, G., Yamanouchi, T., Kawamura, K., and Honda, H.: Carbon dioxide variations in the stratosphere over Japan, Scandinavia and Antarctica, Tellus 55B, 178-186, 2003.

Barkley, M. I., Monks, P. S., and Engelen, R. J.: Comparison of SCIAMACHY and AIRS $\mathrm{CO}_{2}$ measurements over North America during the summer and autumn of 2003, Geophys. Res. Lett., 33, L20805, doi:10.1029/2006GL026807, 2006.

Boering, K. A., Wofsy, S. C., Daube, B. C., Schneider, J. R., Loewenstein, M., Podolske, J. R., and Conway, T. J.: Stratospheric mean ages and transport rates from observations of $\mathrm{CO}_{2}$ and $\mathrm{N}_{2} \mathrm{O}$, Science, 274, 1340-1343, 1996.

Buchwitz, M., de Beek, R., Nol, S., Burrows, J. P., Bovensmann, H., Bremer, H., Bergamaschi, P., Krner, S., and Heimann, M.: Carbon monoxide, methane and carbon dioxide columns retrieved from SCIAMACHY by WFM-DOAS: year 2003 initial data set, Atmos. Chem. Phys., 5, 3313-3329, 2005, http://www.atmos-chem-phys.net/5/3313/2005/.

Chedin, A., Serrar, S., Scott, N. A., Crevosier, C., and Armante, R.: First global measurements of midtropospheric $\mathrm{CO}_{2}$ from NOAA polar satellites: Tropical zone, J. Geophys. Res., 108(D18), 4581, doi:10.1029/2003JD003439, 2003.

Daube, B. C., Boering, K. A., Andrews, A. E., and Wofsy, S. C.: A high-precision fast-response airborne $\mathrm{CO}_{2}$ analyzer for in-situ sampling from the surface to the middle stratosphere, J. Atmos. Ocean. Techn., 19, 1532-1543, 2002.

Engel, A., Bönisch, H., Brunner, D., Fischer, H., Franke, H., Günther, G., Gurk, C., Hegglin, M., Hoor, P., Königstedt, R., Krebsbach, M., Maser, R., Parchatka, U., Peter, T., Schell, D., Schiller, C., Schmidt, U., Spelten, N., Szabo, T., Weers, U., Wernli, H., Wetter, T., and Wirth, V.: Highly resolved observations of trace gases in the lowermost stratosphere and upper troposphere from the Spurt project: an overview, Atmos. Chem. Phys., 6, 283-301, 2006,

http://www.atmos-chem-phys.net/6/283/2006/.

Engelen, R. J. and McNally, A. P.: Estimating atmospheric $\mathrm{CO}_{2}$ from advanced infrared satellite radiances within an operational fourdimensional variational (4D-VAR) data assimilation system: Results and validation, J. Geophys. Res., 110, D18305, doi:10.1029/2005JD005982, 2005.

Fischer, H., Lawrence, M., Gurk, Ch., Hoor, P., Lelieveld, J., Hegglin, M. I., Brunner, D., and Schiller, C.: Model simulations and aircraft measurements of vertical, seasonal and latitudinal $\mathrm{O}_{3}$ and CO distributions over Europe, Atmos. Chem. Phys., 6, 339-348, 2006 ,

http://www.atmos-chem-phys.net/6/339/2006/.
Forster, P., Ramaswamy, V., Artaxo, P., Berntsen, T., Betts, R., Fahey, D. W., Haywood, J., Lean, J., Lowe, D. C., Myhre, G., Nganga, J., Prinn, R., Raga, G., Schulz, M., and Van Dorland, R.: Changes in Atmospheric Constituents and in Radiative Forcing, in: Climate Change 2007: The Physical Science Basis, Contribution of Working Group I to the Fourth Assessment Report of the Intergovernmental Panel on ClimateChange, edited by: Solomon, S., Qin, D., Manning, M., Chen, Z., Marquis, M., Averyt, K. B., Tignor, M., and Miller, H. L., Cambridge University Press, Cambridge, United Kingdom and New York, NY, USA, 129-234, 2007.

Hoor, P., Gurk, C., Brunner, D., Hegglin, M. I., Wernli, H., and Fischer, H.: Seasonality and extent of extratropical TST derived from in-situ CO measurements during SPURT, Atmos. Chem. Phys., 4, 1427-1442, 2004,

http://www.atmos-chem-phys.net/4/1427/2004/.

Hoor, P., Fischer, H., and Lelieveld, J.: Tropical and extratropical tropospheric air in the lowermost stratosphere over Europe: A CO-based budget, Geophys. Res. Lett., 32, LO7802, doi:10.1029/2004GL022018, 2005.

Gerbig, C., Lin, J. C., Wofsy, S. C., Daube, B. C., Andrews, A. E., and co-authors: Toward constraining regional-scale fluxes of $\mathrm{CO}_{2}$ with atmospheric observations over a continent: 1 . observed spatial variability from airborne platforms, J. Geophys. Res., 108(D24), 4756, doi:10.1029/2002JD003018, 2003.

Intergovernmental Panel on Climate Change, Climate Change: The scientific basis, contribution of working group 1 to the third assessment report of the Intergovernmental Panel on Climate Change (IPCC), edited by: Houghton, J. T. et al., Cambridge University Press, New York, USA, 2001.

Keeling, Ch. D.: Rewards and penalties of monitoring the earth, Ann. Rev. Energy Environm., 23, 25-82, 1998.

Lawrence, M. G., Rasch, P. J., von Kuhlmann, R., Williams, J., Fischer, H., de Reus, M., Lelieveld, J., Crutzen, P. J., Schultz, M., Stier, P., Huntrieser, H., Heland, J., Stohl, A., Forster, C., Elbern, H., Jakobs, H., and Dickerson, R. R.: Global chemical weather forecasts for field campaign planning: predictions and observations of large-scale features during MINOS, CONTRACE, and INDOEX, Atmos. Chem. Phys., 3, 267-289, 2003, http://www.atmos-chem-phys.net/3/267/2003/.

Lin, J. C., Gerbig, C., Wofsy, S. C., Daube, B. C., Matross, D. M., Chow, V. Y., Gottlieb, E., Andrews, A. E., Pathmathevan, M., and Munger, J. W.: What have we learned from intensive atmospheric field programmes of $\mathrm{CO}_{2}$ ?, Tellus, 58B, 331-343, 2006.

Machida, T., Kita, K., Kondo, Y., Blake, D., Kawakami, S., Inoue, G., and Ogawa, T.: Vertical and meridional distributions of atmospheric $\mathrm{CO}_{2}$ mixing ratios between northern midlatitudes and southern subtropics, J. Geophys. Res., 108, 8401, doi:10.1029/2001JD000910, 2002.

Matsueda $\mathrm{H}$. and Inoue, H. Y.: Measurements of atmospheric $\mathrm{CO}_{2}$ and $\mathrm{CH}_{4}$ using a commercial airliner from 1993 to 1994, Atmos. Environm., 30, 1647-1655, 1996.

Matsueda, H., Inoue, H. Y., and Ishii, M.: Aircraft observations of carbon dioxide at 8-13 km altitude over the western Pacific from 1993-1999, Tellus, 54B, 1-21, 2002.

Masarie, K. A. and Tans, P. P.: Extension and integration of atmospheric carbon dioxide data into a globally consistent measurement record, J. Geophys. Res., 100, 11 593-11 610, 2006.

Nakazawa, T., Miyashita, K., Aoki, S., and Tanaky, M.: Tempo- 
ral and spatial variations of upper tropospheric and lower stratospheric carbon dioxide, Tellus, 43B, 106-117, 1991.

Nakazawa, T., Morimoto, S., Aoki, S., and Tanaka, M.: Time and space variations of the carbon isotope ratio of tropospheric carbon dioxide over Japan, Tellus, 45B, 258-274, 1993.

Olson, S. C. and Randerson, J. T.: Differences between surface and column atmospheric $\mathrm{CO}_{2}$ and implications for carbon cycle research, 2004, J. Geophys. Res., 109, D02301, doi:10.1029/2003JD003968, 2004.

Pearman, G. I. and Beardsmore, D. J.: Atmospheric carbon dioxide measurements in the Australian region: Ten years of aircraft data, Tellus, 36B, 1-24, 1984.

Sawa, Y., Mtsueda, H., Makino, Y., Inoue, H. Y., Murayama, S., Hirota, M., Tsutsumi, Y., Zaizen, Y., Ikegami, M., and Okada, K.: Aircraft observations of $\mathrm{CO}_{2}, \mathrm{CO}, \mathrm{O}_{3}$ and $\mathrm{H}_{2}$ over the North Pacific during the PACE-7 campaign, Tellus, 56B, 2-20, 2004.

Shia, R. L., Liang, M. C., Miller, C. E., and Yung, Y. L.: $\mathrm{CO}_{2}$ in the upper troposphere: Influence of stratospheretroposphere exchange, Geophys. Res. Lett., 33, L14814, doi:10.1029/2006GL026141, 2006.

Stephens, B. B., Guerney, K. R., Tans, P. P., et al.: Weak northern and strong tropical land carbon uptake from vertical profiles of atmospheric $\mathrm{CO}_{2}$, Science, 316, 1732-1735, 2007.

Strahan, S. E., Douglass, A. R., Nielsen, J. E., and Boering, K. A.: The $\mathrm{CO}_{2}$ seasonal cycle as a tracer of transport, J. Geophys. Res., 103, 13 729-13 741, 1998.
Strahan, S. E., Duncan, B. N., and Hoor, P.: Observationally derived transport diagnostics for the lowermost stratosphere and their application to the GMI chemistry and transport model, Atmos. Chem. Phys., 7, 2435-2445, 2007, http://www.atmos-chem-phys.net/7/2435/2007/.

Taylor, F. W.: Elementary Climate Physics, Oxford University Press, Oxford, UK, 2005.

Tiwari, Y. K., Gloor, M., Engelen, R. J., Chevallier, F., Rödenbeck, Ch., Körner, S., Peylin, P., Braswell, B. H., and Heimann, M.: Comparing $\mathrm{CO}_{2}$ retrieved from Atmospheric Infrared Sounder with model predictions: Implications for constraining surface fluxes and lower-to-upper troposphere transport, J. Geophys. Res., 111, D17106, doi:10.1029/2005JD006681, 2006.

Vay, S. A., Anderson, B. E., Conway, T. J., Sachse, G. W., Collins Jr., J. E., Blake, D. R., and Westberg, D. J.: Airborne observations of tropospheric $\mathrm{CO}_{2}$ distribution and its controlling factors over the South Pacific Basin, J. Geophys. Res., 104, 5663-5676, 1999.

Wernli, H. and Davies, H. C.: A Lagrangian-based analysis of extratropical cyclones, I: The method and some applications, Q. J. Roy. Meteor. Soc., 123, 467-489, 1997.

World Meteorological Organization (WMO): Greenhouse Gas Bulletin, No. 2, 2006.

Zahn, A., Neubert, R., Maiss, M., and Platt, U.: Fate of long-lived trace species near the Northern Hemisphere tropopause: Carbon dioxide, methane, ozone, and sulfur hexafluoride, J. Geophys. Res., 104, 13 923-13 942, 1999. 